\title{
New data about orb-weaving spiders (Aranei: Araneidae and Tetragnathidae) from the Russian Far East
}

\section{Новые данные по паукам-кругопрядам (Aranei: Araneidae и Tetragnathidae) Аальнего Востока России}

\author{
Yuri M. Marusik1, Mikhail M. Omelko ${ }^{2,3}$, Pavel S. Simonov ${ }^{4}$, \\ Seppo Koponen ${ }^{5}$ \\ Ю.М. Марусик ${ }^{1}$, М.М. Омелько ${ }^{2,3}$, П.С. Симонов ${ }^{4}$, С. Копонен ${ }^{5}$
}

\footnotetext{
${ }^{1}$ Institute for Biological Problems of the North RAS, Portovaya Str. 18, Magadan, Russia. E-mail: yurmar@mail.ru

${ }^{2}$ Far Eastern Federal University, Sukhanova 8, Vladivostok RF-690950, Russia

${ }^{3}$ Gornotayozhnaya Station FEB RAS, Gornotayozhnoye Vil., Ussuriyski Dist., Primorski Krai, 692533 Russia. E-mail: omelkom@gmail.com

${ }^{4}$ Pacific Institute of Geography FEB RAS, Radio Str. 7, Vladivostok, 690041, Russia E-mail: palzpss@yandex.ru

${ }^{5}$ Zoological Museum, University of Turku, FI-20014 Turku, Finland. E-mail: sepkopo@utu.fi

${ }^{1}$ Институт биологических проблем Севера ДВО РАН, ул. Портовая 18, Магадан 685000, Россия.

2 Дальневосточный Федеральный Университет, Суханова 8, Владивосток, 690950, Россия

${ }^{3}$ Горнотаёжная станция ДВО РАН, с. Горнотаёжное, Уссурийский район, Приморский край, 692533, Россия.

${ }^{4}$ Тихоокеанский институт географии ДВО РАН, ул. Радио 7, Владивосток, 690041, Россия.
}

KEY WORDS: Orb weaver, Araneae, Maritime Province, new synonym, new record.

КЛЮЧЕВЫЕ СЛОВА: кругопряды, Araneae, Приморский край, новый синоним, новая находка.

ABSTRACT. Two species described by Bakhvalov from the Russian Far East are synonymized: Gibbaranea abscissa $($ Karsch, 1879) = Araneus amurius Bakhvalov, 1981, syn.n.; Plebs sachalinensis (S. Saito, 1934) = Araneus russicus Bakhvalov, 1981, syn.n. Two species, Neoscona scylloides Bösenberg et Strand, 1906, Menosira ornata Chikuni, 1955, and one genus, Menosira Chikuni, 1955 are reported from Russia for the first time. Occurrence of Araneus ventricosus (L. Koch, 1879), a sibling species of $A$. macacus Uyemura, 1961, in the Russian Far East (Maritime Province) was confirmed.

РЕЗЮМЕ: Синонимизированы два вида: Gibbaranea abscissa (Karsch, 1879) = Araneus amurius Bakhvalov, 1981, syn.n.; Plebs sachalinensis (S. Saito, 1934) = Araneus russicus Bakhvalov, 1981, syn.n. Впервые для Росиии указаны два вида: Neoscona scylloides Bösenberg et Strand, 1906, Menosira ornata Chikuni, 1955 и один род Menosira Chikuni, 1955. Подтверждена встречаемость на Дальнем Востоке России (Приморский край) Araneus ventricosus (L. Koch, 1879), близкого к A. macacus Uyemura, 1961, вида.

\section{Introduction}

Orb-weaving spiders belonging to Araneidae and Tetragnathidae are among the best-studied spider families in the Russian Far East due to the numerous taxonomic and faunistic publications. Although orbweavers of this region are easy to collect (due to their large size, well-visible webs, etc.) and identify (thanks to numerous identification books on orbweaving spiders of neighboring countries [Chikuni, 1989; Yin et al., 1997; Song et al., 1999; Namkung, 2002; Zhu et al. 2003; Tanikawa, 2007; Ono et al. 2009 , etc.]), this group remains insufficiently studied in the Russian Far East. Two main reasons for this are that (a) some species were poorly described, their generic placement is incorrect, and their types are lacking [cf. Šestáková et al., 2014]; and (b) existing collection material on orb-weaving spiders is insufficient. In our ongoing study of Russian Far East spiders, we recognized two synonyms, two poorly documented species, and one species and one genus new to Russia. The main goal of this paper is to provide comments on new synonymies and newly discovered or rediscovered species in Khabarovsk and Maritime Provinces.

\section{Material and methods}

Digital photographs were taken in dishes of different sizes with paraffin covered bottom. Specimens were photographed using an Olympus Camedia E520 camera attached to an Olympus SZX16 stereomicroscope at the Zoological Museum, University of Turku, Finland, and Axio Cam HRc fastened to Zeiss 

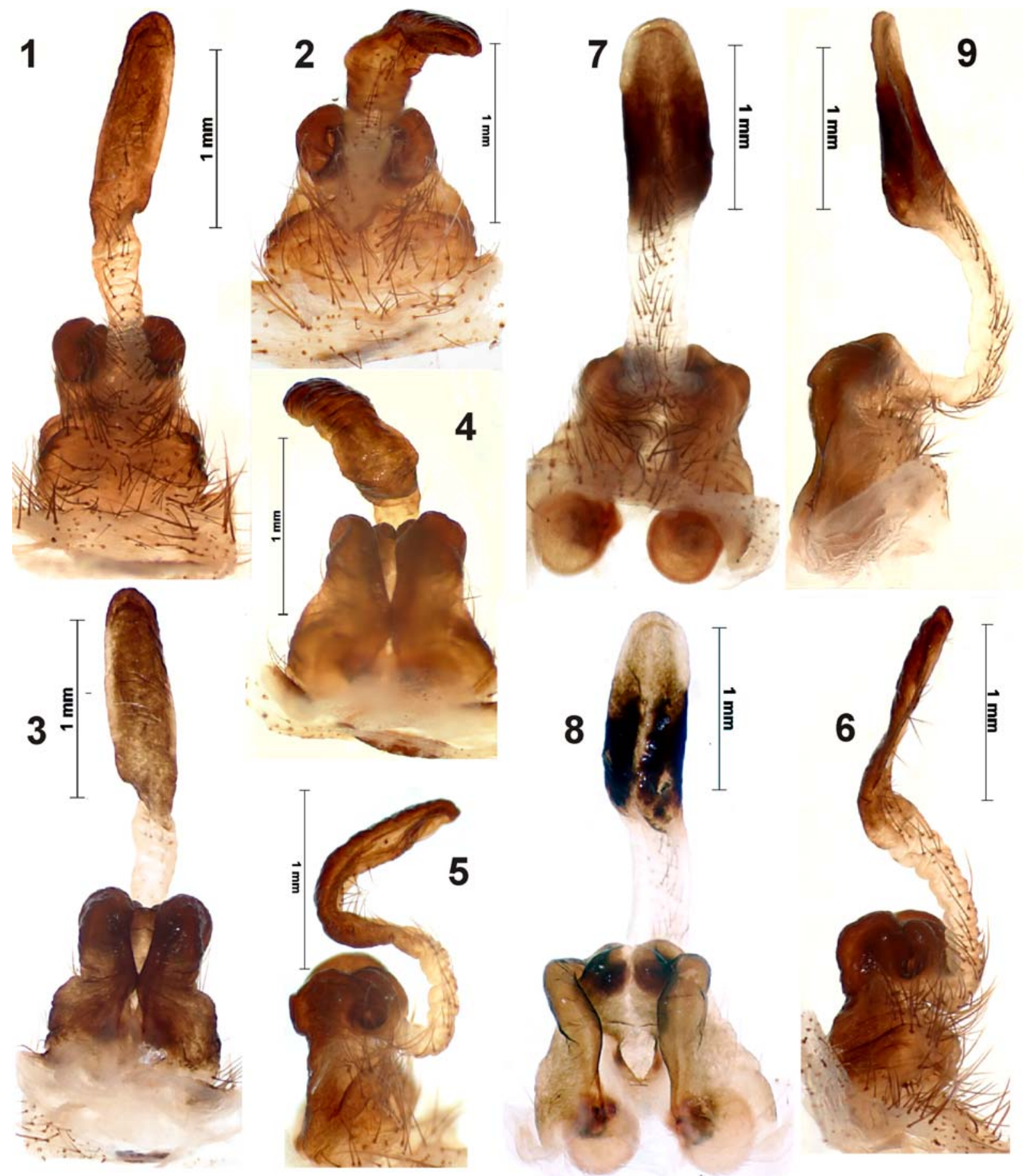

Figs 1-9. Epigynes of Araneus macacus (1-6) and A. ventricosus (7-9): 1-2, 7 - ventral; 3-4, 8 - caudal; 5-6, 9 - lateral.

Рис. 1-9. Эпигины Araneus macacus (1-6) и A. ventricosus (7-9): 1-2, 7 - вентрально; 3-4, 8 — каудально; 5-6, 9 — латерально.

SteREO Discovery V12 stereomicroscope (Institute of Biology and Soil Sciences, Vladivostok, Russia). Digital images were prepared using CombineZP image stacking software. Illustrations of epigynes were made after maceration in $20 \%$ potassium hydroxide aqueous solution. Material studied here will be deposited in the Zoological Museum of Moscow State University (ZMMU) and Institute for Biological Problems of the North, Magadan (IBPN).

\section{Taxonomic survey}

Family ARANEIDAE

Araneus ventricosus (L. Koch, 1879)

Figs 7-9.

A. v.: Tanikawa, 2007: 78, f. 223-226, 651-653, 658-659 ( ( + ); Tanikawa, 2009: 452, f. 230-233 (ऽ'o). 
For a complete list of all 41 taxonomic references see World Spider Catalog [2015].

MATERIAL EXAMINED. RUSSIA: 3 ㅇ (ZMMU), Maritime Province, Vladivostok, Tigrovaya Hill, $43.062^{\circ} \mathrm{N} 131.522^{\circ} \mathrm{E}$, multiherb meadow with sparse elms, 20-30.06.2012 (P.S. Simonov).

COMPARATIVE MATERIAL. Araneus macacus: RUSSIA: Maritime Province: 5 우 (GTS), Shkotovo District, $1.5 \mathrm{~km} \mathrm{~S}$ of Lukyanovka Village, $43.082^{\circ} \mathrm{N} 132.422^{\circ} \mathrm{E}$, Carex-herb-shrub meadow, 13.08.2012 \& 16.07.2014 (P.S. Simonov); 2 O $^{7} \sigma^{7} 1$ (IBPN), Lazo Reserve, Sukhoi Klyuch Gorge, mixed forest, 11.08.1976 (T.I. Oliger). Sakhalin: 2 우 (IBPN), SW part, Krilyon Peninsula, $\mathrm{W}$ shore, ca $5 \mathrm{~km} \mathrm{~S}$ of Shebunino Village, Kitosia River mouth, $36^{\circ} 22.536^{\prime} \mathrm{N} 141^{\circ} 52.562^{\prime} \mathrm{E}, 14-15.08 .2001$ (Y.M. Marusik).

COMMENTS. Araneus ventricosus is a well-known, and possibly the largest species of Araneidae found through the entire Russia. This species was reported from numerous localities from Khabarovsk and Maritime Provinces; however, its occurrence in the Russian Far East was doubted by Logunov \& Marusik [2004] because most of identifications referred to a sibling species, A. macacus Uyemura, 1961. Study of the specimens collected in Vladivostok show that, while most of large-sized Araneus from there belong to A. macacus, the species $A$. ventricosus also occurs in Russia, at least in the southern part of Maritime Province. Two species well differ by the shape of epigyne in caudal view: lateral margins of posterior plate are widely separated and not touching in $A$. ventricosus while in $A$. macacus lateral margins touch each other and partially hide posterior plate. General appearance of two species is very similar.

DISTRIBUTION. This species is restricted to southeastern Palaearctic, but exact limits of its range are uncertain since its sibling species $A$. macacus is often confused with $A$. ventricosus.

\section{Gibbaranea abscissa (Karsch, 1879)}

Figs 10-16.

\section{Epeira a. Karsch, 1879: 69 ().}

Araneus amurius Bakhvalov, 1981: 142, f. 1 (†). Syn.n.

Araneus abscissus: Chikuni, 1989: 67, f. 18 ( ( 7 ( $)$.

G. a.: Tanikawa, 2007: 76, f. 210-211, 633-634 (ठㅇ); Tanikawa, 2009: 450, f. 212-213 ( $\sigma^{\top}+$ ).

For a complete list of all 21 taxonomic references see World Spider Catalog [2015].

MATERIAL EXAMINED. RUSSIA: Maritime Province: 2 $\sigma^{7} \sigma^{7} 1+$ (ZMMU), environs of Kiyevka Vil., clear cutting in oak forest, 11.06 .1975 (T.I. Oliger); $1 O^{7} 2$ 우 (IBPN), Lazo town (district center), in an apartment, 1.03.2002 (Yu. Sundukov).

COMMENTS. Bakhvalov [1981] described Araneus amurius from the environs of Khabarovsk based on the holotype female. Description of this species is very brief. Bakhvalov paid special attention to eyes and spination (although spination was given in unclear format). In Bakhvalov's diagnosis, A. amurius was compared with Larinioides cornutus and L. folium. Araneus amurius was found to differ from these species by its spination as well as by coloration pattern and shape of epigyne. Judging from the figure of epigyne (Fig. 16), A. amurius undoubtedly belongs to Gibbaranea. Here, we synonymize it with G. abscissa, the single representative of this genus in the Russian Far
East [cf. Mikhailov, 2013], reported from environs of Khabarovsk [Marusik et al., 2007]. We were not able to compare the holotype of Araneus amurius with specimens of G. abscissa due to lack of this type; unfortunately. Bakhvalov's types were lost after his death [Šestáková et al., 2014].

DISTRIBUTION. The species is restricted to Southeastern Palaearctic. It is known from Amur Area, Khabarovsk and Maritime Provinces in Russia, from northeastern China (Hebei, Liaoning, Jilin and Heilongjiang Provinces), Korea, and Japan.

\section{Neoscona scylloides Bösenberg et Strand, 1906} Figs 17-28.

N. s.: Tanikawa, 1998: 153, f. 38, 62-68 ( ('0); Tanikawa, 2007: 70, f. 177-180, 591-593 (o'o); Tanikawa, 2009: 445, f. 170$172\left(\mathrm{O}^{\top}+\right)$.

For a complete list of all 28 taxonomic references see World Spider Catalog [2015].

MATERIAL EXAMINED. RUSSIA: 1 juv. (ZMMU), Maritime Province, suburb of Vladivostok, $43.072^{\circ} \mathrm{N} 131.582^{\circ} \mathrm{E}$, shrubby Carex-Graminacea meadow, 2.08 .2013 (P.S. Simonov). JAPAN: $1 \sigma^{\gamma} 1$ (ZMMU), Kagoshima Prefecture, Takara Island, 7.07.2007 (A. Tanikawa).

COMMENTS. Although only a single subadult female was found in Vladivostok, it was easy to identify this species with certainty. There are only two Neoscona species with green-colored abdomen in the Southeastern Palaearctic, N. scylloides and N. mellotteei (Simon, 1895). These two species can be easily separated due to black venter of abdomen in $N$. mellotteei [cf. fig. 35 in Chikuni, 1989]. Bright green coloration fades in alcohol (Figs 20-21, 25). Female of this species has a very long epigyne, much longer than in other Neoscona species known from Russia and adjacent countries. Neoscona scylloides was found in Russia for the first time.

DISTRIBUTION. This species has a Palaearchaearctic range and is known, besides Vladivostok (the northernmost locality in the range), from Japan, Korea, Taiwan, and the eastern half of China.

Plebs sachalinensis (S. Saito, 1934)

Figs 29-35.

Argiope s. Saito, 1934a: 332, f. 6 (+).

Araneus russicus Bakhvalov, 1981: 144, f. 3 (†). Syn. n.

Zilla s. Chikuni, 1989b: 74, f. 36 ( $\sigma^{7}+$ )

Eriophora s. Tanikawa, 2000: 23, f. 7, 15-17 ( $\left.\sigma^{\top}+\right)$; Tanikawa, 2007: 67, f. 140-141, 564-565 (o'o); Tanikawa, 2009: 441, f. 144-145 ( $\left.\sigma^{7}+\right)$.

For a complete list of all 43 taxonomic references see World Spider Catalog [2015].

COMMENTS. Araneus russicus was described based on a single female from the environs of Khabarovsk. As other Bakhvalov's type, holotype of A. rusticus is considered lost. Judging from the figure of epigyne and size of the holotype, it is conspecific with Plebs sachalinensis and is here synonymized to this senior name.

Pattern on carapace and abdomen in this species is highly variable (Figs 29-30). Digital photographs (Figs 


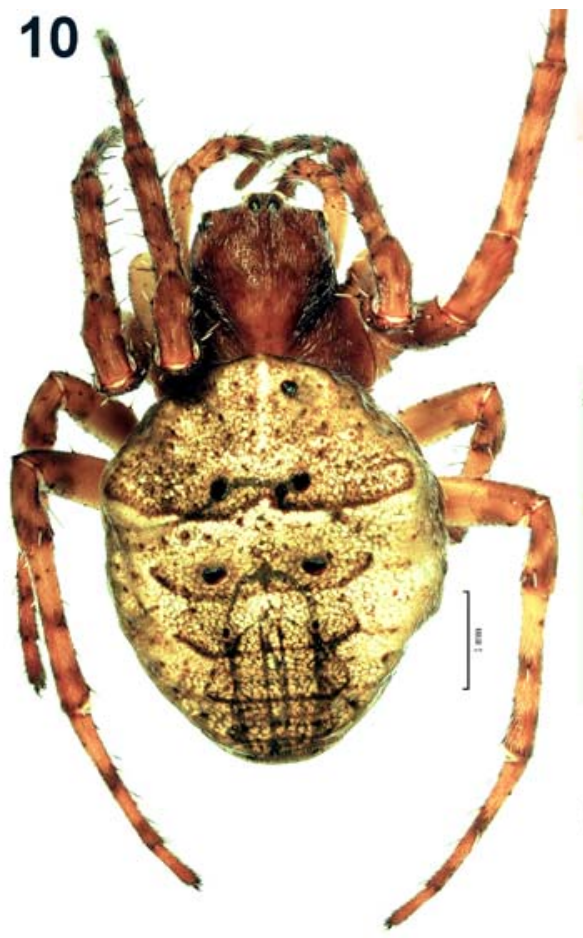

11

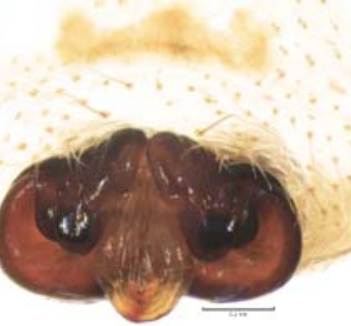

13
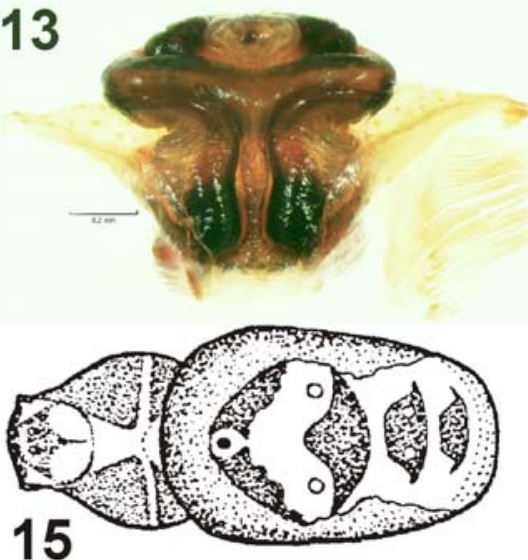

12
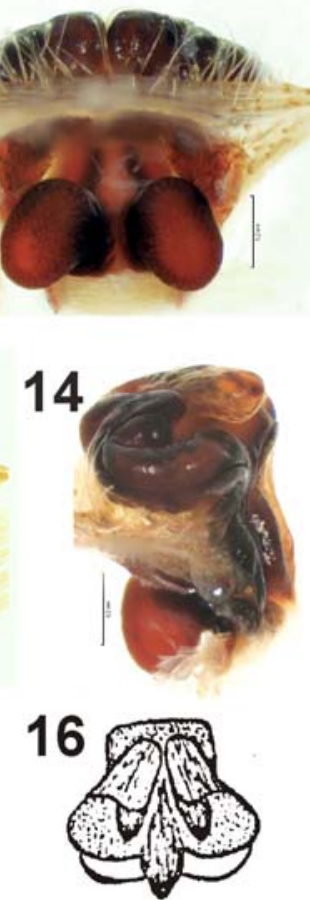

Figs 10-16. Female of Gibbaranea abscissa: 10, 15 - habitus, dorsal; 11, 16 - epigyne ventral; 12-15 - epigyne, anterior, caudal and lateral. 15-16 - after Bakhvalov [1981].

Рис. 10-16. Самка Gibbaranea abscissa: 10, 15 - внешний вид, дорзально; 11, 16 - эпигина, вентрально; 12-15 - эпигина, спереди, каудально и латерально. 15-16 - по Bakhvalov [1981].
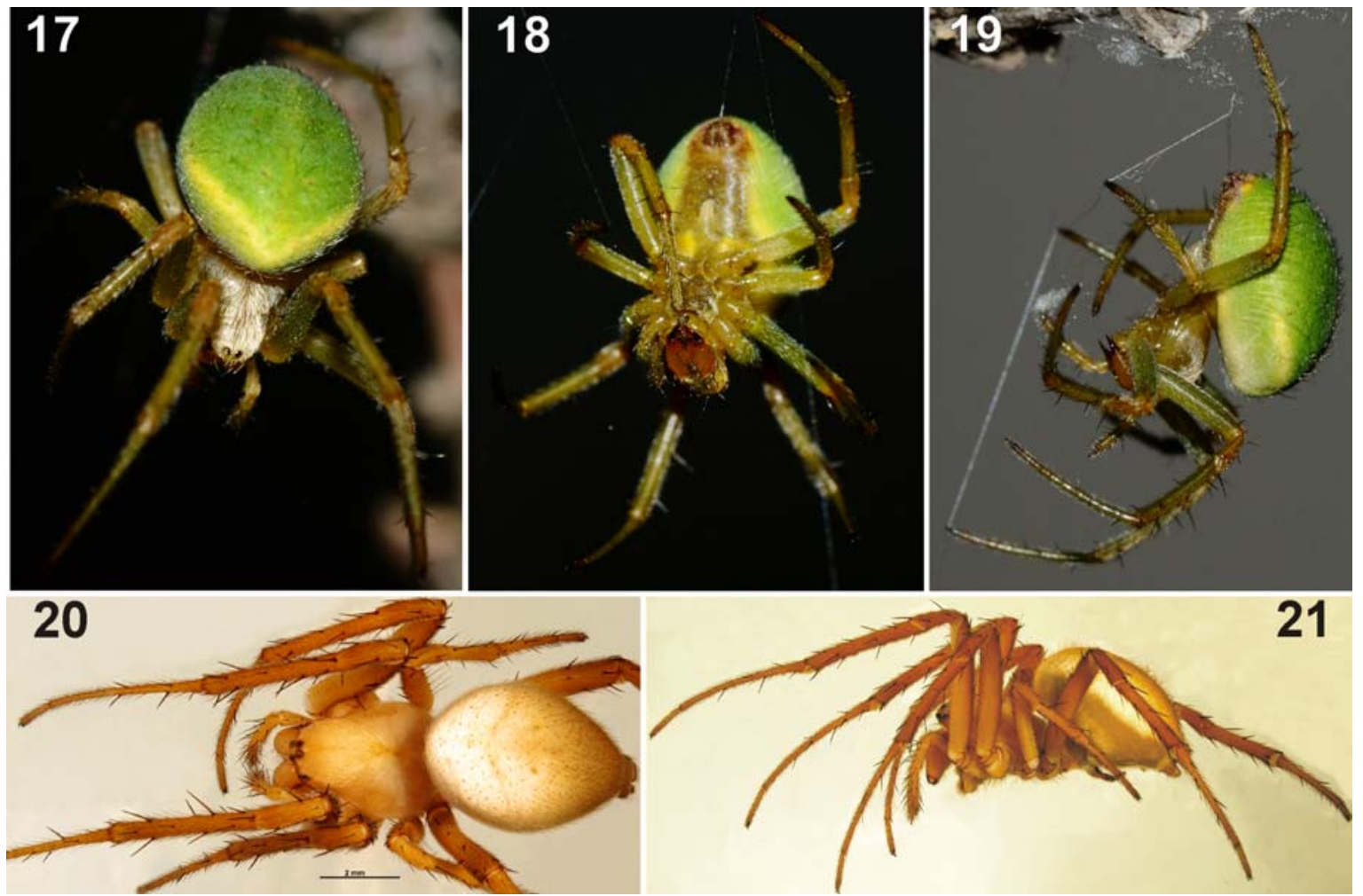

Figs 17-21. Neoscona scylloides habitus and pattern of live subadult female from Maritime Province (17-19) and female from Japan kept in alcohol (20-21): 17, 20 - dorsal; 18 - ventral; 19, 21 - lateral.

Рис. 17-21. Neoscona scylloides внешний вид и окраска живой предполовозрелой самки из Приморского края (17-19) и самки из Японии в спирту (20-21): 17, 20 - дорзально; 18 - вентрально; 19, 21 - латерально. 

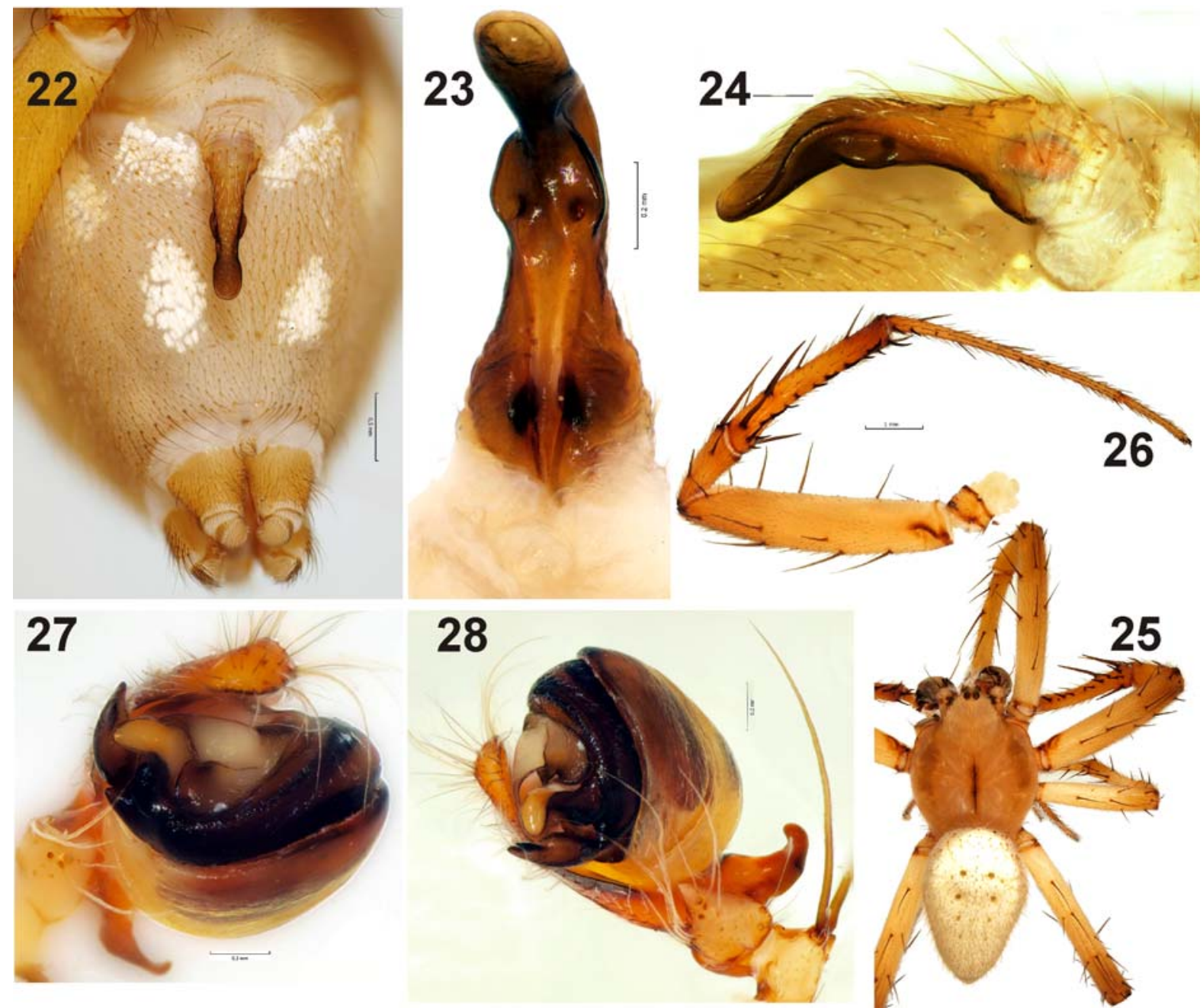

Figs 22-28. Neoscona scylloides, specimens from Japan: 22 - venter of abdomen, showing length of epigyne and pattern; $23-$ epigyne, dorsal; 24 - epigyne, lateral; 25 - male habitus, dorsal; 26 - male leg II prolateral; $27-28$ - male palp, anterior and anterioventral.

Рис. 22-28. Neoscona scylloides, экземпляры из Японии: 22 - низ брюшка, показана длина эпигины и окраска; 23 - эпигина, дорзально; 24 - эпигина, латерально; 25 - внешний вид самца, дорзально; 26 - нога II самца пролатерально; 27-28 — пальпа самца, спереди и спереди-снизу.

32-33) differ from a figure of epigyne (Fig. 34) provided by Bakhvalov due to a different angle.

DISTRIBUTION. This species has a Palaearchaearctic range. It is widely distributed across the Russian Palaearchaearctic (Amur Area, Khabarovsk and Maritime Provinces, South Kurils, and southern Sakhalin) and in adjacent northeastern China, Korea, and Japan.

\section{Family TETRAGNATHIDAE}

\section{Genus Menosira Chikuni, 1955}

COMMENTS. This monotypic genus was not yet properly reported from Russia, and was not included in most recent catalog of Russian spiders [Mikhailov, 2013]. A male of Menosira ornata was illustrated by Marusik \& Kovblyuk [2011], but no comments were provided about its occurrence in Russia. Male palp of Menosira is very similar to that of Metellina Chamber- lin \& Ivie, 1941, and the two genera possibly will be synonymized in future.

$$
\begin{gathered}
\text { Menosira ornata } \text { Chikuni, } 1955 \\
\text { Figs 36-43. }
\end{gathered}
$$

M. o.: Chikuni, 1989: 92, f. 9 (०'o); Tanikawa, 2007: 96, f. 320-

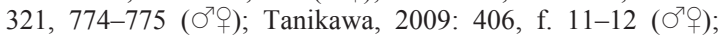
Marusik, Kovblyuk, 2011: 235, f. $34.21\left(\mathrm{O}^{\mathrm{T}}\right)$.

For a complete list of all 28 taxonomic references see World Spider Catalog [2015].

MATERIAL EXAMINED. RUSSIA: Maritime Province: 3 $\sigma^{7} O^{7} 2$ 우 (ZMMU), Kedrovaya Pad' Reserve, 16.09.2008 (D. Osipov). Kuril Islands: 1 (IBPN), SW Kunashir Island, Ivanovsky Cape, 20-30.09.2013 (Yu. Sundukov).

COMMENTS. This species well differs from other Metinae found in the Russian Far East by the unique pattern and shape of copulatory organs (Figs 36-43). Prolateral spines on metatarsi I-II resemble those in Mimetidae (Figs 36, 38). 

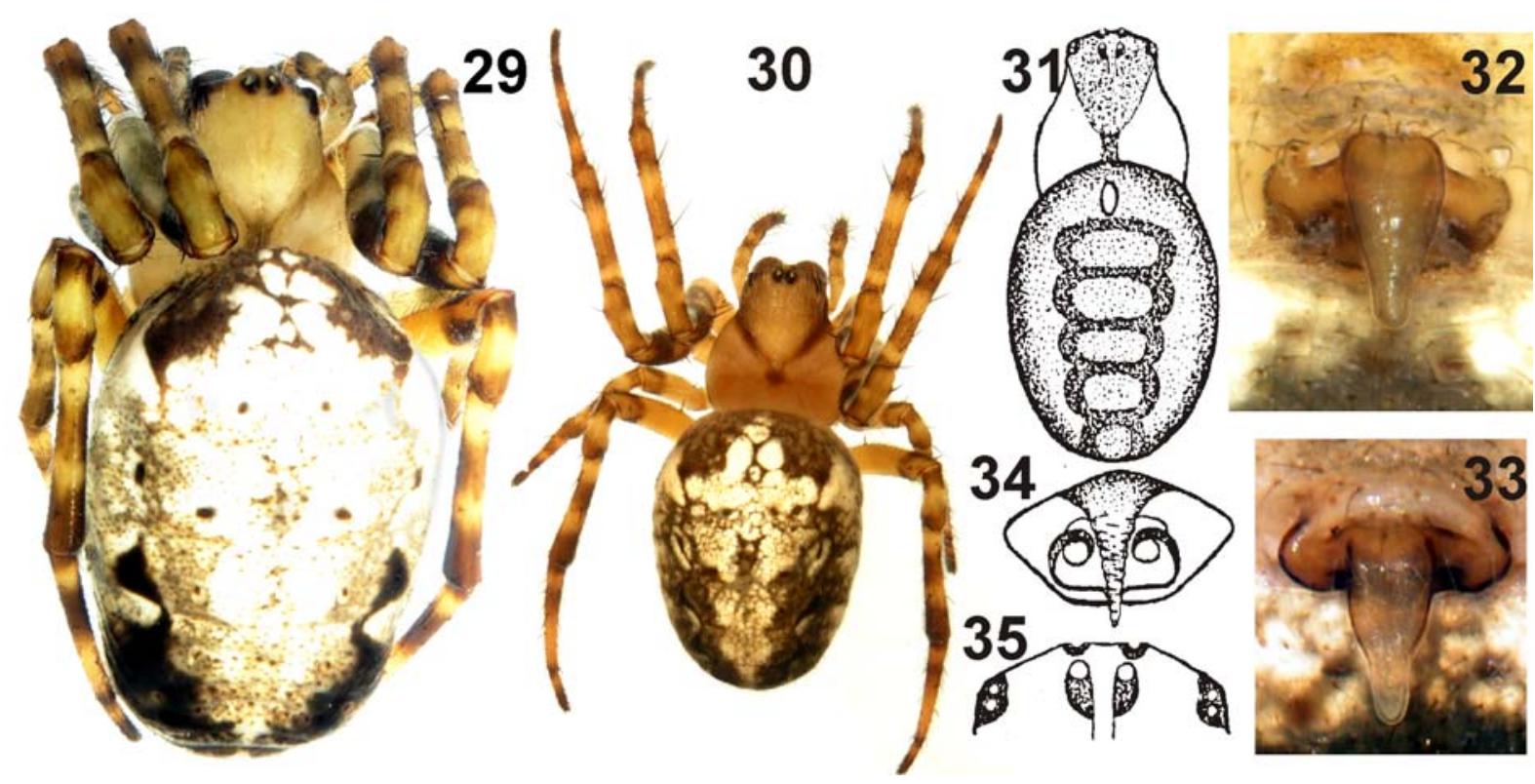

Figs 29-35. Female of Plebs sachalinensis: 29-31 - habitus, dorsal; 32-34 - epigyne, ventral; 35 - eye field. 31, 34-35 - after Bakhvalov [1981].

Рис. 29-35. Самка Plebs sachalinensis: 29-31 - внешний вид, дорзально; 32-34 - эпигина, вентрально; 35 - глазная область. 31, 34-35 - по Bakhvalov [1981].

DISTRIBUTION. This species has a Palaearchaearctic range and is known from south part of Maritime Province, Japan, Korea and eastern China (Hubei Province). Kunashir Island is the northernmost locality in the entire range.

ACKNOWLEDGEMENTS. We are grateful to Daniil Osipov (Moscow), Yuri Sundukov (Kurilski Reserve), Tatiana I. Oliger (Niznesvirski Reserve, Russia) and Akio Tanikawa (Tokyo, Japan) who provided us with some of the specimens used in this study. We thank Kirill Mikhailov for editing the manuscript, and Mykola M. Kovblyuk (Simferopol) for a review. English of the final draft was checked by Victor Fet (Huntington, USA). This work was supported in part by the Far Eastern Federal University and Russian Foundation for Basic Research (grant \#15-14-05964).

\section{References}

Bakhvalov V.F. 1981. [New species of orb-weaving spiders (Aranei, Araneidae) from Siberia and Soviet Far East] // Entomologicheskie issledovaniya v Kirgizii. Vol.14. P.142-150 [in Russian].

Chikuni Y. 1989. [Pictorial Encyclopedia of Spiders in Japan]. Kaisei-sha Publ. Co. Tokyo. 310 pp. [in Japanese].

Karsch F. 1879. Baustoffe zu einer Spinnenfauna von Japan // Verhandlungen des Naturhistorischen Vereins der Preussischen Rheinlande, Westfalens und des Reg.-Bez. Osnabrük Bd.36. S.57-105.
Logunov D.V., Marusik Yu.M. 2004. [Order Araneae - spiders] // Bioraznoobrazie Sokhondinskogo zapovednika. Chlenistonogie. Novosibirsk-Chita. P.41-80 [in Russian].

Marusik Yu.M., Kovblyuk M.M. 2011. Spiders (Arachnida, Aranei) of Siberia and Russian Far East. Moscow: KMK Scientific Press. 344 pp. [in Russian].

Marusik Yu.M., Tanasevitch A.V., Kurenshchikov D.K., Logunov D.V. 2007. A check-list of the spiders (Araneaea) of the Bolshekhekhtsyrski Nature Reserve, Khabarovsk Province, the Russian Far East // Acta Arachnologica Sinica. Vol.16. No.1. P.37-64.

Mikhailov K.G. 2013. The spiders (Arachnida: Aranei) of Russia and adjacent countries: a non-annotated checklist // Arthropoda Selecta. Supplement No.3. 262 pp.

Namkung J. 2002. [The spiders of Korea]. Seoul: Kyo-Hak Publishing Co. 648 pp. [in Korean].

Ono H. 2009. [The Spiders of Japan with keys to the families and genera and illustrations of the species]. Kanagawa: Tokai University Press. 739 pp. [in Japanese].

Saito S. 1934. A supplementary note on spiders from southern Saghalin, with descriptions of three new species // Transactions of the Sapporo Natural History Society. Vol.13. No.3. P.326-340.

Šestáková A., Marusik Yu.M., Omelko M.M. 2014. A revision of the Holarctic genus Larinioides Caporiacco, 1934 (Araneae: Araneidae) // Zootaxa. Vol.3894. No.1. P.61-82.

Song D.X., Zhu M.S., Chen J. 1999. The Spiders of China. Shijiazhuang: Hebei Sci. Technol. Publ. House. 640 pp.

Tanikawa A. 1998. A revision of the Japanese spiders of the genus Neoscona (Araneae: Araneidae) // Acta arachnologica. Vol.47. No.2. P.133-168.

Tanikawa A. 2000. Japanese spiders of the genus Eriophora (Araneae: Araneidae) // Acta arachnologica. Vol.49. No.1. 17-28.

Figs 36-43. Female (36-37) and male (38-43) of Menosira ornata: 36, 38 - habitus, dorsal; 37 - epigyne, ventral; 39 - habitus, lateral; 40 - palp, retrolateral; 41-43 - terminal part of palp, ventral, retrolateral and dorsal.

Рис. 36-43. Самка (36-37) и самец (38-43) Menosira ornata: 36, 38 - внешний вид, дорзально; 37 - эпигина, вентрально; 39 внешний вид, латерально; 40 - пальпа, ретролатерально; 41-43 - конечная часть пальпы, вентрально, ретролатерально и дорзально. 

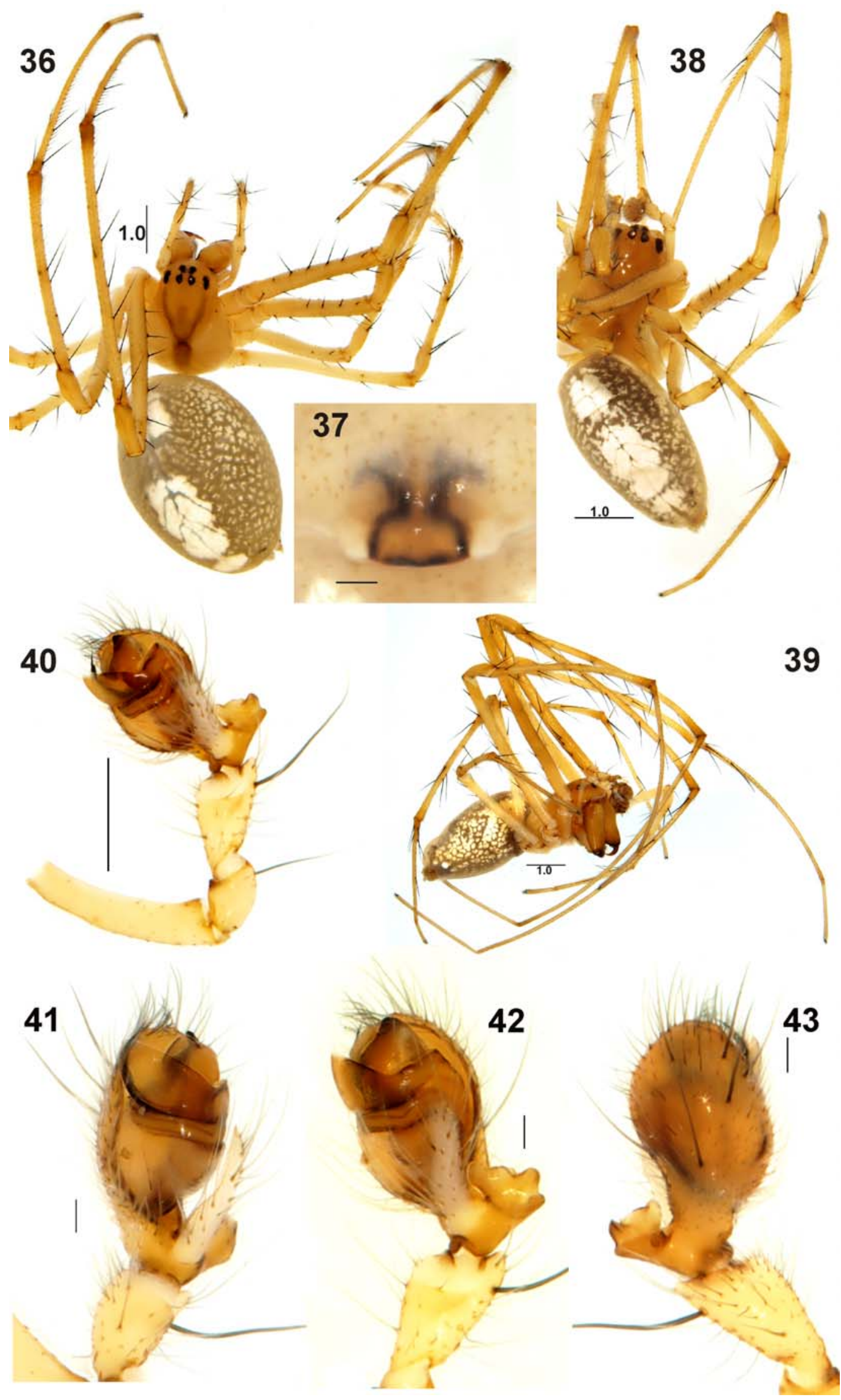
Tanikawa A. 2007. [An identification guide to the Japanese spider of the families Araneidae, Nephilidae and Tetragnathidae]. Arachnological Society of Japan. 121 pp. [in Japanese].

Tanikawa A. 2009. [Hersiliidae. Nephilidae, Tetragnathidae, Araneidae] // Ono H. (ed.). The Spiders of Japan with keys to the families and genera and illustrations of the species. Tokai Univ. Press. Kanagawa. P.149, 403-463 [in Japanese].

World Spider Catalog. 2015. / Natural History Museum Bern, online at http://wsc.nmbe.ch, version 16 , accessed on January $20,2015$.
Yin C.M., Wang J.F., Zhu M.S., Xie L.P., Peng X.J., Bao Y.H.. 1997. [Fauna Sinica: Arachnida: Araneae: Araneidae]. Beijing: Science Press. 460 pp. [in Chinese].

Zhu M.S., Song D.X., Zhang J.X. 2003. [Fauna Sinica: Invertebrata Vol.35: Arachnida: Araneae: Tetragnathidae]. Beijing: Science Press. 418 pp. [in Chinese].

Responsible editor K.G. Mikhailov 